\title{
Desenvolvimento versus crescimento: as contradições no município de Itaguaí - RJ
}

Lamounier Erthal Villela

Cezar Augusto Miranda Guedes

Marcelo de Oliveira Vidal

Daniel Neto Francisco ${ }^{1}$

\section{Resumo}

O munícipio de Itaguaí, junto com o Estado do Rio de Janeiro, é segundo a FIRJAN (2013) a região no mundo que recebe a maior quantia de investimentos em valor absoluto. Este artigo objetiva verificar como o boom de investimentos no município vem encadeando mudanças nas estruturas locais. Esse crescimento induzido pelos Grandes Projetos de Investimentos GPIs estaria se traduzindo no desejado desenvolvimento territorial sustentável? Os poderes públicos locais e a sociedade civil do município estão em sintonia com essas transformações? Através de pesquisas de campo, contrapontos teóricos e dados disponíveis sobre os investimentos no município, políticas públicas e participação social, busca-se neste artigo traçar um panorama das forças de inércia e de mudança que induzem os avanços e as perspectivas para o local.

Palavras-chave: Crescimento Econômico; Desenvolvimento Sustentável; Governança Territorial; Gestão Social

\begin{abstract}
The municipality of Itaguai, along with the State of Rio de Janeiro, is the area in the world that receives the second largest amount of investments in absolute value (FIRJAN, 2013). This article aims to verify how the investment boom in the city has taken to changes in local structures. Is this economic growth induced by Large Investment Projects driving the area to the Sustainable Territorial Development? The local authorities and civil society of the county are in line with these changes? Through field research, theoretical counterpoints and data on investments in the municipality, public policy and public participation, this paper gives an overview of changes and perspectives for the local development in the city.
\end{abstract}

Keywords: Economic Growth; Sustainable Development; Territorial Governance; Public Participation

\footnotetext{
1 Lamounier Erthal Villela é professor do Departamento de Economia e Coordenador do Programa de Pós-Graduação em Desenvolvimento Territorial e Políticas Públicas DeCE / PPGCTIA / PPGDT / UFRRJ. lamounier.erthal@gmail.com

Cezar Augusto Miranda Guedes é professor do Departamento de Economia e do Programa de Pós-Graduação em Desenvolvimento Territorial e Políticas Públicas DeCE / PPGCTIA / PPGDT / UFRRJ. cezar.eco@gmail.com

Marcelo de Oliveira Vidal é pós-doutorando em Desenvolvimento Territorial e Políticas Públicas PPGDT / UFRRJ. celovidal@hotmail.com

Daniel Neto Francisco é mestrando em Desenvolvimento Territorial e Políticas Públicas PPGDT / UFRRJ. danielneto@id.uff.br
} 


\section{Introdução}

O Estado do Rio de Janeiro recebeu, entre os anos de 2011 e 2013, investimentos públicos e privados que somam 181,4 bilhões de reais. Comparado com a dimensão territorial do estado (43,7 mil km²), o volume do investimento é de mais de $\mathrm{R} \$ 4$ milhões por quilômetro quadrado, fazendo do Estado do Rio de Janeiro o maior concentrador de investimentos do mundo (FIRJAN, 2013). Entre estes destacam-se os investimentos em Itaguaí: 1) A ampliação do Porto de Itaguaí, localizado na baía de Sepetiba, com a realização de obras de ampliação da área de manobra e dragagem, que permite acesso de navios mercantes de grande porte; construção de terminais para o Grupo EBX, para a Companhia Siderúrgica Nacional-CSN e para a Thiessen-Krupp Companhia Siderúrgica do Atlântico - TKCSA, além de dois novos terminais a serem operados pela Companhia Docas do Rio de Janeiro (CDRJ); 2) A duplicação da rodovia BR-101 (Rio-Santos), no trecho entre a cidade do Rio de Janeiro e o distrito de Itacuruçá, no Município de Mangaratiba, atravessando todo o Município de Itaguaí que, articulado com o Arco Metropolitano, vai facilitar o acesso ao Porto de Itaguaí; 3) A construção do Arco Metropolitano, inaugurado em 1 de julho de 2014, com uma extensão de 145 quilômetros, ligando o Complexo Petroquímico da Petrobras em Itaboraí, chamado Complexo Petroquímico do Rio de Janeiro (COMPERJ) ao Porto de Itaguaí;

Figura 1

Arco Metropolitano do Rio de Janeiro

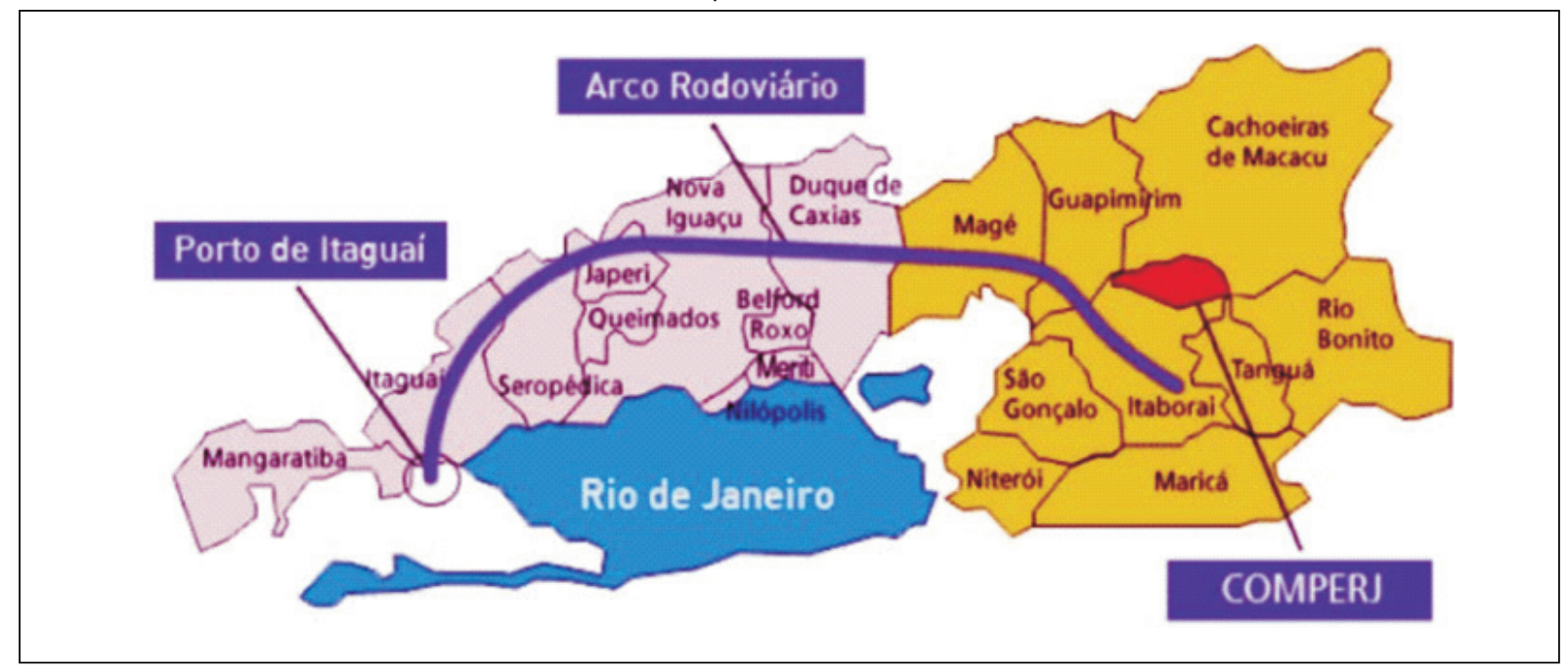

Fonte: RIMA-COMPERJ (2007)

4) A Construção da siderúrgica da TKCSA, inaugurada em junho de 2010, no Distrito Industrial do bairro de Santa Cruz, divisa com o Município de Itaguaí e que terá suporte logístico de acesso, rodovia, ferrovia e terminal próprio no Porto de Itaguaí; 5) A construção de um estaleiro e base naval para a produção de submarinos atômicos na ilha da Madeira em Itaguaí, inaugurado em 1 de março de 2013. A Figura 2 mostra a divisão do Município de Itaguaí e os espaços ocupados pelos GPIs (Grandes Projetos de Investimentos). 


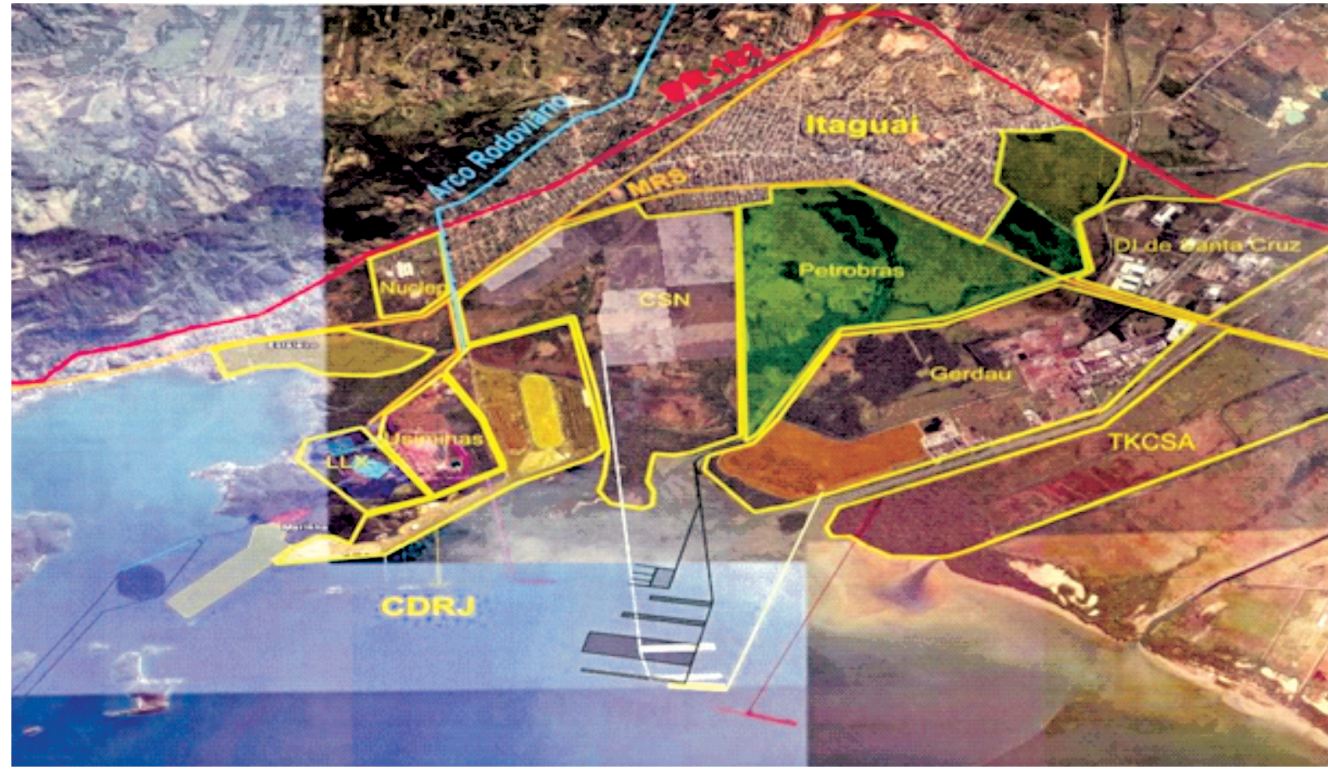

Fonte: Google imagens (2014).

O aumento expressivo da receita do Município de Itaguaí em função da arrecadação proveniente dos GPIs abre, em uma primeira análise, a possibilidade de que sejam planejadas iniciativas do poder público que visem minimizar os impactos negativos desses investimentos. Dessa forma, as transformações em curso no município encadeiam a necessidade de uma governança territorial capaz de dialogar sobre as demandas criadas pelo mercado, pela sociedade civil e pelos poderes públicos. Supõe-se teoricamente que o diálogo entre os segmentos envolvidos no processo de transformação possa resultar de um desenvolvimento sustentável consolidando coesão social e territorial, governabilidade, sustentabilidade, inclusão econômica e bem-estar. No entanto, na prática esse diálogo que visa o bem comum pode ser inexistente ou de difícil concílio. No caso específico de Itaguaí, pesquisas anteriores (Santana et al., 2011; Villela et al., 2012) apontam que o atual crescimento econômico de Itaguaí não está induzindo a um desenvolvimento sustentável. Os dados sobre o município que serão descritos em seção posterior deste artigo apontam aumento de arrecadação fiscal, de transferências governamentais e que o município teve aumento expressivo no número de empregos criados, principalmente na fase inicial de construção civil. Desses fatos, alguns questionamentos surgem e neste artigo os colocamos como uma agenda para reflexão: Esse crescimento estaria se traduzindo no aumento das inversões em serviços básicos e consequentemente na melhoria da qualidade de vida da população local? O crescimento econômico trazido pelos Grandes Projetos de Investimentos - GPIs estariam gerando o desejado desenvolvimento territorial sustentável? Ou estariam totalmente descolados da realidade das pessoas que vivem no município? Os poderes públicos locais e a sociedade civil do município estão em sintonia com as demandas impostas pelos GPIs?

Nesse sentido, este artigo busca verificar o aumento das receitas do município entre os anos 2011 e 2013, e a evolução dos principais serviços públicos neste período a fim de verificar impactos positivos e negativos dos GPIs. Para desenvolver o artigo utilizamos os seguintes aportes teóricos: os conceitos de GPI (Furtado, 1980; Vainer, 2001; Brandão, 2010) e suas imbricações entre gestão social, controle social (Tenório, 2008; Villela, 2008), controle 
social e desenvolvimento territorial sustentável (Perico, 2009); também os aspectos referentes ao planejamento urbano no que concerne às políticas públicas sugeridas pelo Ministério das Cidades, como planos diretores e o papel dos conselhos municipais no controle social. Os aspectos metodológicos buscam a aplicação da teoria na prática seguindo um viés de análise crítica, através da qual foram elaboradas: pesquisa bibliográfica, tematizada, documental e de campo. As pesquisas contribuíram para mapear as ações dos poderes públicos (municipal, estadual, federal) no Município de Itaguaí. Foram tratados dados obtidos no IBGE, DATASUS, Inea, Prefeitura e Câmara de Itaguaí, Tesouro Nacional, FIRJAN e Ipeadata. Também foram feitas diversas incursões no campo para elaboração de entrevistas junto a representantes dos poderes públicos locais e conselheiros municipais.

\section{1 - Dialogando a Teórica e a Prática}

O Brasil tem larga tradição em planejamento e implantação de grandes projetos, seja na área industrial, de infraestrutura ou energia, tendo sido um dos poucos países a promover a desterritorialização de sua capital, ao transferi-la do Rio de Janeiro para Brasília, a meta síntese do Plano de Metas no governo Juscelino Kubitscheck. Aliás, foi a partir dos anos cinquenta do século passado - auge do período desenvolvimentista - que os setores de construção pesada e os serviços de engenharia se tornaram um dos principais elos no tecido empresarial brasileiro. O BNDE (o S de social só viria compor a sigla em 1986) foi inaugurado em 1952 (governo Vargas) com sua agenda focada no binômio "transporte e energia" e desde então é o grande financiador de grandes projetos no Brasil, tendo ampliado sua agenda para quase todos os segmentos da economia brasileira. Neste período se consolida um novo padrão de industrialização no Brasil - industrialização pesada - caracterizado pela implantação da indústria de bens de consumo duráveis e bens de capital, portanto mais próximo de uma matriz industrial da segunda revolução industrial.

Marcados pela criatividade do período desenvolvimentista, entre os anos trinta e o final dos anos setenta, a economia brasileira cresceu como poucas no mundo. Nos anos setenta, mesmo tendo acumulado desequilíbrios regionais, macroeconômicos e distributivos, o Brasil implanta vários GPIs e se tornou exportador de serviços de engenharia. No governo Geisel (1974-1978), o II PND foi elaborado como um ambicioso plano de política industrial e, ao mesmo tempo, uma tentativa de estender o ciclo expansivo da economia. Um desses projetos foi localizado em Itaguaí, com a instalação da Nuclebrás Equipamentos Pesados S.A. (Nuclep), como parte do Programa Nuclear Brasileiro, e que integrou o II Plano Nacional de Desenvolvimento. Acompanhando esse movimento, diversos outros empreendimentos industriais menores foram instalados na região. Na década de oitenta também havia a perspectiva de implantação de um complexo petroquímico, que não se concretizou. Nos anos seguintes, as mudanças no cenário político econômico fizeram com que esses empreendimentos não resultassem no desenvolvimento esperado para o município (Villela et al, 2012).

Apesar dessa grande tradição brasileira em GPIs e seus impactos, o debate e a reflexão crítica de análises a respeito do tema só ganham dimensão anos depois.

Em termos do debate a respeito dos GPIs e da atuação do BNDES, vale destacar a iniciativa da "Plataforma BNDES" (www.plataformabndes.gov.br), criada em 2007. Trata-se de uma iniciativa de 27 organizações que tem por finalidade o reconhecimento e a centralidade do papel de um banco de fomento para a economia e a sociedade brasileira, como é o caso do 
BNDES, mas também ressaltando sua natureza de empresa pública que deveria incorporar outros critérios como a transparência na concessão dos esquemas de financiamento, assim como algumas condicionalidades de natureza socioambiental e trabalhista. Justamente por não se tratar de um banco comercial, essa discussão é lícita e pertinente.

Os GPIs que vêm sendo implantados na região estudada são caracterizados por sua dimensão e impacto em relação ao território em que foi instalado, gerando rupturas nas escalas de poder preestabelecidas. Para Vainer (2001), os GPIs não contribuem para a diminuição das disparidades e desigualdades existentes entre as regiões do país. Ao contrário, as regiões onde estão esses projetos sofrem, de modo geral, com a "desestruturação das atividades econômicas preexistentes, o crescimento desordenado da população, desemprego, favelização, marginalização social e, quase sempre, degradação ambiental”.

De outro lado, esses projetos são "geradores de novos locais", que atraem recursos econômicos, visibilidade, investimentos e geram novas oportunidades de mão-de-obra. De acordo com Silva e Souza (2010), a implementação dos GPIs tem ajudado o país a competir no mercado internacional. Entretanto, como vem se verificando em Itaguaí, discursos de que a chegada dos GPIs podem ajudar no crescimento socioeconômico local através da geração de empregos acabam não se concretizando.

A ruptura nas escalas de poder preestabelecidas e já mencionada é resultado da inserção de novos atores sociais no processo socioeconômico e histórico da região. Martins (1993) destaca que nesse momento conflitos serão desencadeados, pois haverá um embate entre o novo e o antigo e a criação de novas relações sociais que dependerão, na maioria das vezes, de políticas públicas eficientes para dirimir os seus prejuízos materiais, sociais, culturais e políticos. Apesar dos aspectos levantados por Martins, também pode existir uma cooptação de poderes, ou seja, os atores de maior poder econômico podem corromper os poderes locais de modo a satisfazer os seus interesses no curto prazo. Tais questões são apresentadas e discutidas em blogs locais; uma matéria emblemática de cooptação de poder público por políticos locais foi publicada em O Globo: OTAVIO, C. O 'x' do negócio, (Caderno de economia, p. 33, 12 jun. 2011). Segundo tal artigo, os “donos do poder local” elaboram negócios milionários com as grandes empresas locais, como a prática de supervalorização imobiliária entre outras mazelas. No outro "lado da moeda" estão os indicadores socioeconômicos que não apresentam melhorias na rapidez esperada. Isso se deve, em parte, à ligação entre o poder local e o global, em que o segundo pode funcionar como limitador do primeiro especialmente no caso do desenvolvimento através dos GPIs, que estão imersos em escalas distintas daquelas do poder local, ou seja, são inseridas no território através de investimentos nacionais ou do capital transnacional.

Nesse contexto, "importa identificar a natureza do sistema de dominação: seu relacionamento com a estratificação social, seus meios de legitimação, sua organização no espaço, seus meios de reprodução etc.” (Furtado, 1980:33). No que se refere ao poder local frente às transformações estruturais, Brandão (2010:111) destaca que "cabe averiguar estruturas decisórias e a natureza da atuação dos agentes econômicos, por exemplo, do mundo da finança e do mundo produtivo e procurar entender como vai se redefinindo, no processo histórico, o modo de relacionamento entre os heterogêneos espaços urbano-regionais”. Isto posto, caberia às forças sociais locais e ao poder público, através do processo de planejamento e controle, procurar conter essas lógicas instrumentais da escala global e promover o avanço sociopolítico e cidadão no âmbito local.

Para que esse novo arranjo dos atores sociais seja, de alguma forma, benéfico para a 
população local, é necessário que haja uma maior participação da população local nos processos decisórios, ou seja, uma ampliação do controle social por meio de instrumentos que legitimem a participação. No entanto, este caminho não parece ser o trilhado na chegada dos GPIs em localidades onde os poderes públicos locais e a participação social não alcançaram maturidade e instrumentalidade institucional para entenderem os processos de transformação em andamento no local. O que pode o poder local? Este deveria se impor às transformações globais e reduzir as desigualdades locais, no entanto, indaga Vainer (2001:27), "podemos dizer que cada cidade é campo e objeto de relações de apropriação de recursos - materiais, políticos, simbólicos - que resultam das formas particulares únicas que estruturam o poder e as relações econômicas." Vainer complementa que o poder local teria importante papel na redução das desigualdades e melhoria das condições de vida, avanço de dinâmicas sociais de participação e enfraquecimento dos grupos e coalizões dominantes.

A gestão social seria o caminho para a emancipação, pois incita a um “[...] gerenciamento mais participativo, dialógico, no qual o processo decisório é exercido por meio de diferentes sujeitos sociais” (Tenório, 2008b:25-26). Na gestão social “[...] a hegemonia das ações possui caráter intersubjetivo. Isto significa que os interessados na decisão, na ação de interesse público são participantes do processo decisório” (Tenório e Saravia, 2006:128).

Entende-se que a gestão das demandas da sociedade pode acontecer para além do Estado, via sociedade e dinâmicas territoriais. Por outro lado, a gestão social enquanto processo, vista como uma modalidade específica de gestão (nível organizacional), busca "subordinar as lógicas instrumentais [típicas da gestão privada/estratégica] a outras lógicas, mais sociais, políticas, culturais ou ecológicas” (França Filho, 2008:30).

Nesse contexto percebe-se a clara ligação entre os conceitos de GPIs, desenvolvimento territorial sustentável e gestão social. Os impactos dos GPIs sobre o desenvolvimento dos territórios são extremamente complexos e não podem ser deixados no "piloto automático" das lógicas cegas do mercado. É imprescindível um planejamento territorial com participação social para que sejam minimizados os impactos negativos. Em Itaguaí observa-se a baixa participação social acompanhada do enfraquecimento das dinâmicas territoriais locais em virtude dos GPIs. Nesse sentido esses empreendimentos dependem de planos diretores que ordenem os territórios.

O Estatuto de Cidade (2007) define o Plano Diretor como "instrumento básico para orientar a política de desenvolvimento e de ordenamento da expansão urbana do município”. É uma lei municipal elaborada pela Prefeitura com a participação da Câmara Municipal e da sociedade civil que visa estabelecer e organizar o crescimento, o funcionamento, o planejamento territorial da cidade e orientar as prioridades de investimentos. O Plano Diretor visa orientar as ações do poder público compatibilizando os interesses coletivos, garantindo os benefícios da urbanização, os princípios da reforma urbana, o direito à cidade e à cidadania e a gestão democrática da cidade.

A elaboração do plano diretor pode ou deveria implicar, ao mesmo tempo, um processo destrutivo, com a ruptura dos padrões de desenvolvimento do "status quo" e rearranjo das relações de poder, e outro construtivo, com a idealização de uma nova realidade urbanística.

Embora seja comumente encomendado como mera formalidade burocrática, inclusive no município objeto deste estudo, o plano diretor envolveria uma complexidade técnica que depende da colaboração multidisciplinar de profissionais habilitados (em geral de engenheiros, arquitetos, urbanistas, geólogos, geógrafos, topógrafos etc.) e da atuação de equipes especializadas na elaboração dos seus elementos. 
O Estatuto da Cidade contém normas de ordem pública e de interesse social, que propõem regular o uso da propriedade urbana em prol do bem coletivo, da segurança e do bem-estar dos cidadãos, assim como do equilíbrio ambiental (art. $1^{\circ}$, parágrafo único), objetivando ordenar o pleno desenvolvimento das funções sociais da cidade.

Nesse momento busca-se levar em conta os interesses da sociedade civil prestigiando os princípios constitucionais da democracia participativa e da publicidade dos atos da Administração, pois, segundo o art. 40, § $4^{\circ}$, I a III, no processo de elaboração do plano diretor e na fiscalização de sua implementação, o Legislativo e o Executivo devem assegurar a participação da população e de associações representativas dos vários segmentos da comunidade, assim como a publicidade e o acesso a documentos e informações produzidos durante esse processo.

Essa participação na discussão do plano diretor implica dificuldades: primeiro porque o governo municipal, preocupado com seu programa partidário, compromissos eleitorais de curto prazo e sendo avesso a ingerências de grupos setoriais ou ideológicos, tenderá a fazer preponderar sua proposta de planejamento, que pode não representar a aspiração coletiva; segundo porque haverá necessidade de compor os interesses em conflito, que disputam o mesmo direito de utilizar a cidade de acordo com suas conveniências (setor produtivo imobiliário, industrial, comercial, de serviços, movimentos sociais, arquitetos, urbanistas, moradores etc.).

O plano diretor deveria ser considerado como um pacto entre os poderes públicos, o mercado e a sociedade civil. No entanto, a construção deste pacto guarda razão substantiva e não apenas instrumental. A compreensão da importância do plano diretor no bem comum deveria ser a principal força motriz para o acompanhamento e controle social das transformações locais. Nesse sentido a literatura aponta tanto a necessidade de se criarem instrumentos que facilitem a participação social (Lascoumes e Le Galès, 2004) quanto de se definirem contratos e pactos sociais (Gaudin, 2007). Negociar as diretrizes de planos de desenvolvimento local passa por um processo de aprendizado. Ferraz (2014), ao estudar o papel dos conselhos locais no acompanhamento do Plano Diretor de Desenvolvimento Sustentável do Município de Itaguaí - PDDSMI, conclui que a participação social é extremamente baixa no que concerne ao acompanhamento e controle do plano pelos poderes públicos locais e pelo mercado. Em outras palavras o plano não foi pactuado pela sociedade e também não se caracteriza na prática como um instrumento de política pública. Nesse sentido tem-se uma supremacia do mercado sobre a transformação estrutural do local.

O desenvolvimento territorial sustentável deve ser construído a partir da coesão social e territorial assim como a capacidade de governabilidade, sustentabilidade de ações, inclusão econômica e bem-estar social. Logo, a não pactuação do Estado, do mercado e da sociedade civil no desenvolvimento do PDDSMI aponta fraca coesão social, territorial e uma governabilidade não diretiva ao bem comum e à sustentabilidade.

Dados os impactos dos GPIs na localidade, o BIRD - Banco Interamericano de Desenvolvimento contratou a elaboração de um plano de desenvolvimento sustentável para a Baía de Sepetiba (COBRAPE, 2014). Tal plano repetindo a prática tecnocrática, apesar de apontar a necessidade de diálogo, na realidade não buscou dialogicidade com a sociedade local. Ou seja, o plano mapeia os impactos socioeconômicos e ambientais, porém não incita o local ao controle social. Os PDDSMI e o Plano de Desenvolvimento Sustentável da Baía de Sepetiba não cumprem o papel de buscar equacionar a assimetria de forças no local. Por outro lado, as proposições teóricas sobre poder local e participação apresentadas no texto são 
opostas à pratica dos poderes no Município de Itaguaí-RJ. Fica assim a reflexão sobre o que é o local e o que poderia ser.

\section{2 - Investimentos e serviços públicos em Itaguaí: o contraste entre a receita do município e as realizações na área}

Para verificar a realidade dos serviços públicos no Município de Itaguaí vis-à-vis as questões relacionadas ao incremento populacional aliado ao mal uso do dinheiro público, recorremos a dados que mostram o aumento da receita na cidade ao longo do tempo principalmente no período em que as obras dos GPIs iniciam - e aos panoramas da educação, saúde e cultura e lazer.

O Gráfico 1 mostra o aumento da renda própria do município. O Índice Firjan de Gestão Fiscal (IFGF) é um indicador bastante adequado para mostrar os ganhos de receita que o município teve em função dos GPIs. As variáveis que compõem o índice incluem receita própria (22,5\%), gasto com pessoal $(22,5 \%)$, investimentos $(22,5 \%)$, liquidez $(22,5 \%)$ e custo da dívida (10\%). O indicador Receita Própria mede a capacidade de arrecadação de cada município e sua dependência das transferências de recursos dos governos estadual e federal. A média de Itaguaí para o período de 2006 a 2011 foi de 0,8795 o que significa que o município, a princípio, teria grande autonomia para fazer políticas públicas abrangentes.

Gráfico 1

IFGF - Receita Própria

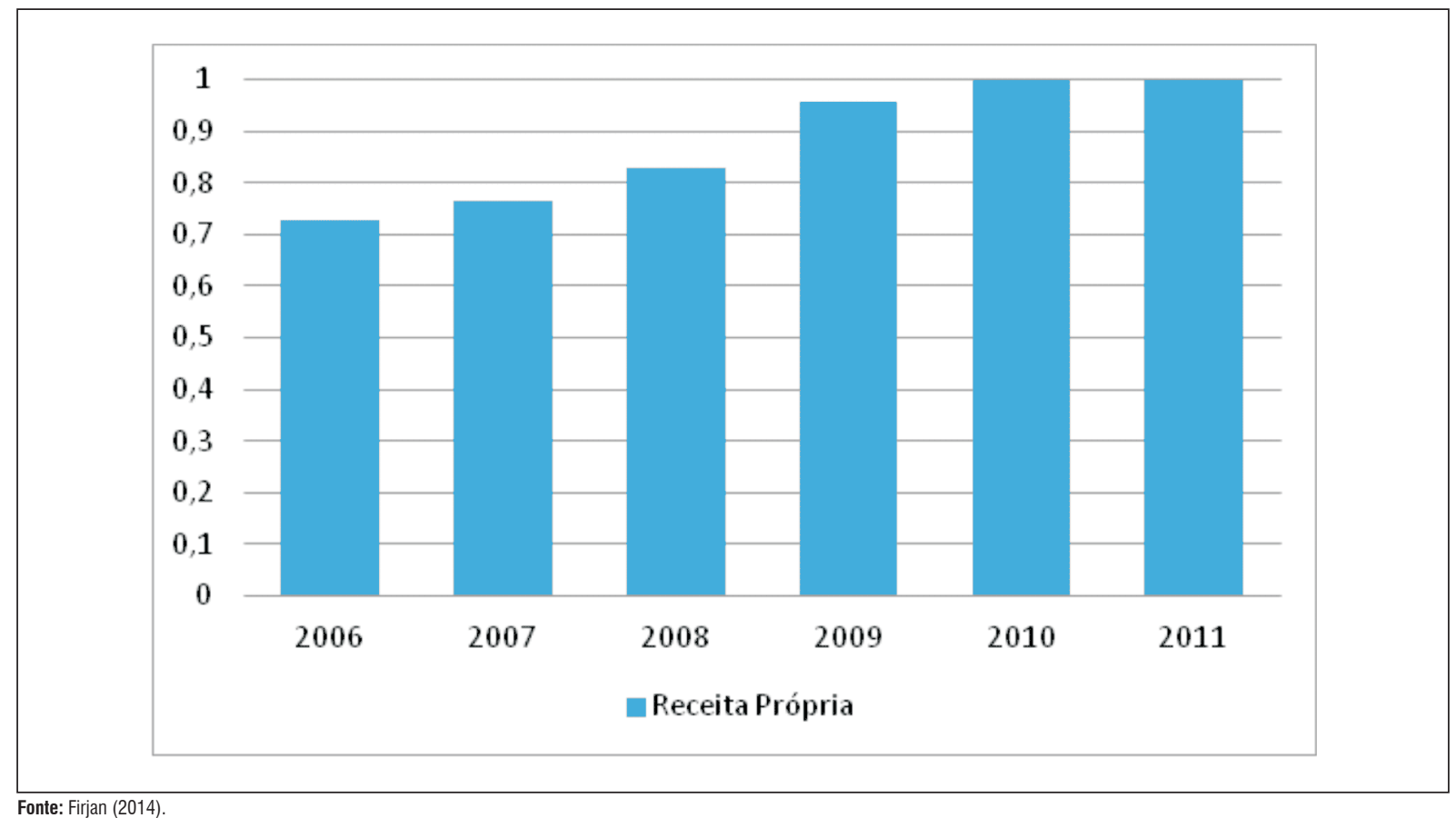

Ao mesmo tempo, a população de Itaguaí cresce em função dos GPIs, o que faz crescer a necessidade de melhorias no nível do ensino. No Gráfico 2 observa-se um crescimento do número de habitantes a partir dos anos 2000, período a partir do qual o número de pessoas vivendo na cidade vai de 82.003 para 115.542 em 2013 (IBGE, 2014). 
Gráfico 2

Crescimento populacional de Itaguaí (1999 - 2013)

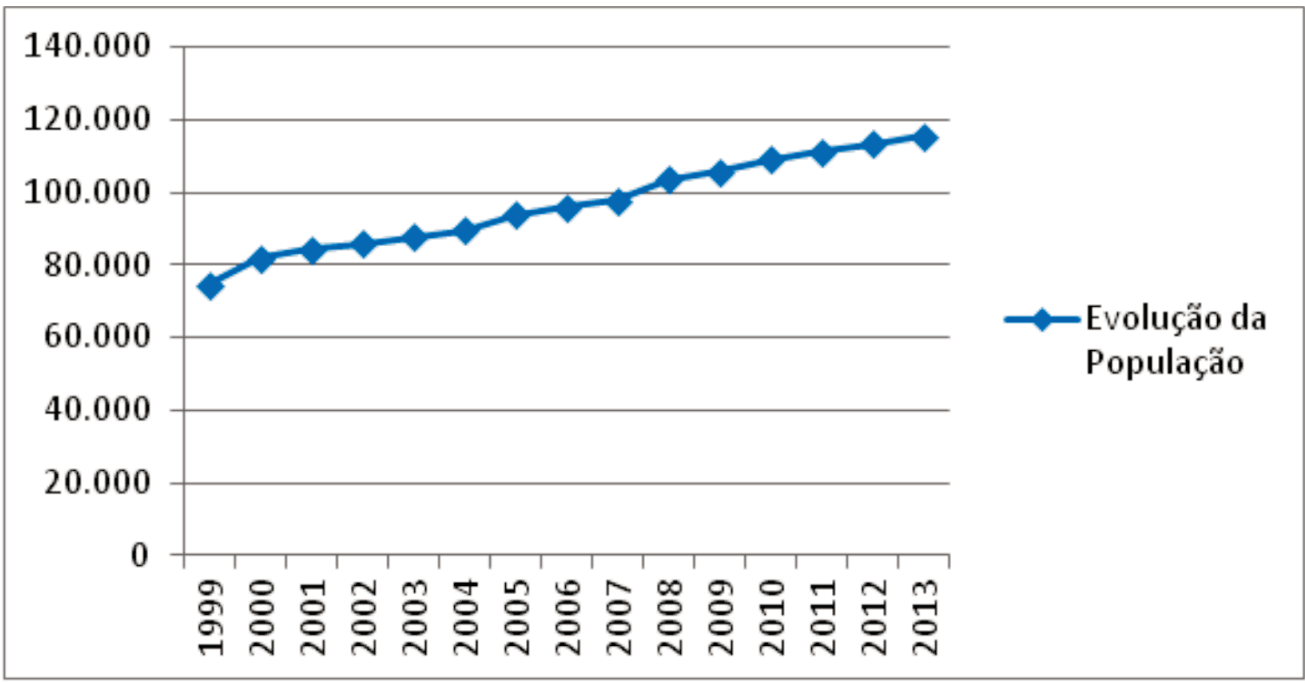

Fonte: Compilado a partir de IBGE (2014)

\subsection{Educação}

Ao mesmo tempo em que as receitas próprias crescem significativamente entre 2006 e 2011, como é possível observar no Gráfico 3, a composição das receitas constitucionais também cresce, num movimento que acontece em nível nacional e reflete uma melhora relativa dos serviços públicos de educação em todo país. A singularidade de possuir investimentos dos GPIs da ordem de bilhões, no entanto, não traz benefícios adicionais à cidade, como será possível perceber mais à frente.

No Gráfico 3 observa-se que as transferências constitucionais crescem de cerca de 10 milhões de reais em 2004 para 60 milhões em 2013.

Gráfico 3

Composição das Transferências Constitucionais

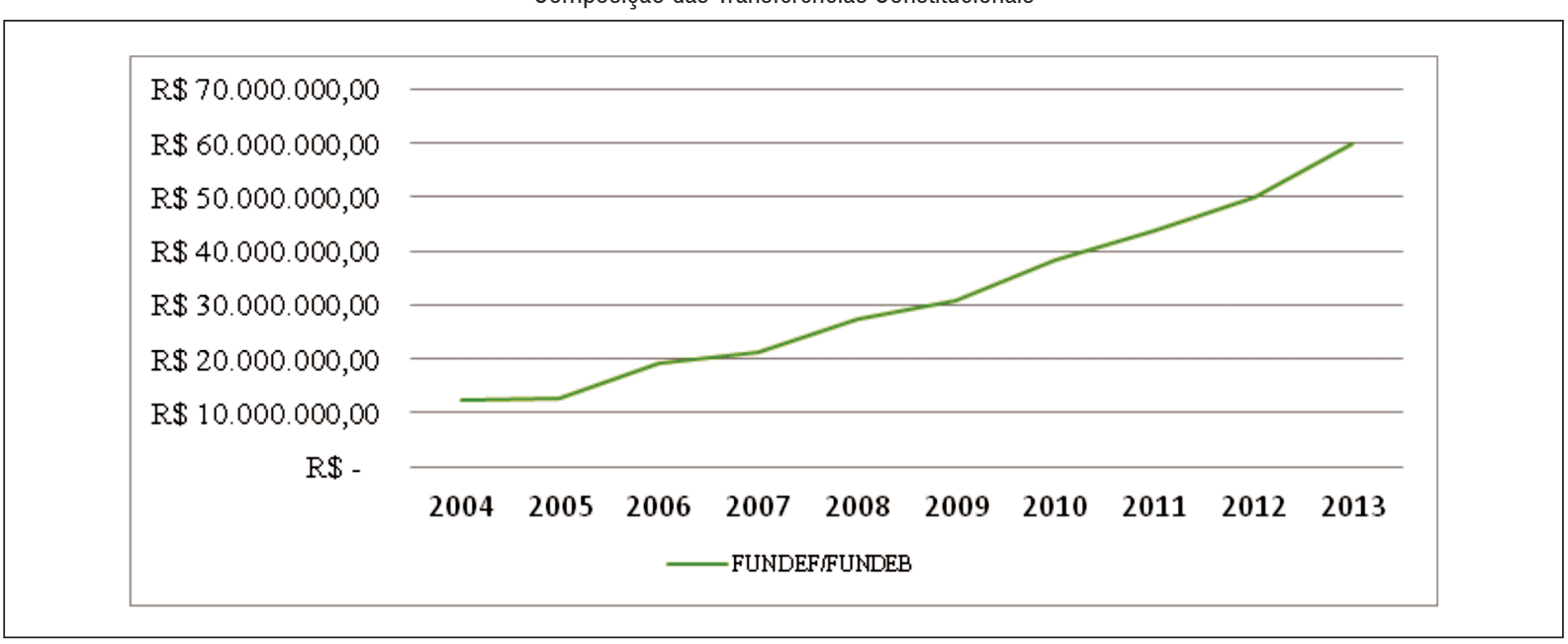

Fonte: Compilado a partir de Prefeitura (2014)

De outro lado, os gastos com educação apresentam uma queda de $24 \%$ no último ano, embora tenham crescido 96\% no período de 2008 a 2013 em função principalmente do aumento das transferências constitucionais, cenário este que se repete em grande parte do país independentemente da existência de GPIs. Dessa forma, é possível perceber que há um 
descolamento entre os investimentos feitos a partir dos GPIs e a melhoria da qualidade de vida da população local e imigrante através da educação.

Gráfico 4

Gastos com Educação

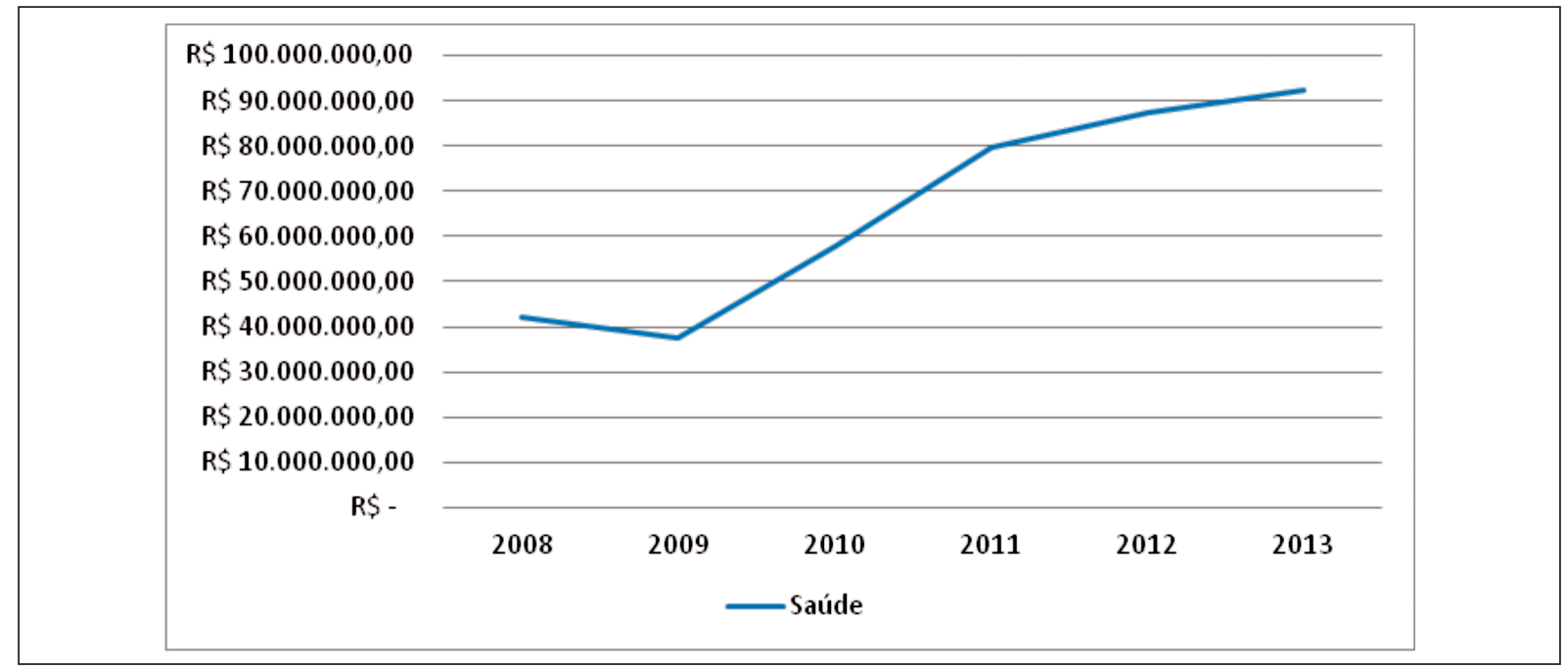

Fonte: Compilado a partir de Prefeitura (2014).

Verificou-se ainda que Itaguaí não conseguiu universalizar o acesso, pois 4,96\% das crianças de 5 a 6 anos ainda não ingressaram na escola. Este cenário vai piorando na medida em que se acompanham os números das séries mais avançadas. Segundo o Atlas Brasil (2013), "a proporção de crianças e jovens frequentando ou tendo completado determinados ciclos indica a situação da educação entre a população em idade escolar do município e compõe o IDHM (Índice de Desenvolvimento Humanos dos Municípios) Educação”. Verifica-se, neste caso, que a proporção de alunos cursando os diferentes módulos na idade recomendada vai decrescendo com o avançar dos ciclos escolares. Em 2010, apenas 9,42\% dos alunos de 18 a 24 anos estavam cursando o ensino superior; 23,95\% dos jovens de 15 a 17 anos estavam cursando o ensino médio regular sem atraso; e 52,31\% dos alunos entre 6 e 14 anos estavam cursando o ensino fundamental regular. O município apresenta algumas carências de equipamentos escolares nas várias esferas, principalmente no ensino superior, que é praticamente inexistente. Dessa forma, parte da população é obrigada a se deslocar para os municípios mais próximos (Seropédica, Rio de Janeiro, Niterói e Volta Redonda), que oferecem campus universitários. Verificou-se que quase que a totalidade dos gastos, 89,14\%, é direcionada ao Ensino Fundamental, já que Itaguaí não possui uma rede municipal de Ensino Médio.

\subsection{Saúde}

Entre os setores analisados, os gastos com saúde foram um dos que mais cresceram chegando a um aumento de 118\% no período de 2008 a 2013. 
Gráfico 5

Gastos com Saúde

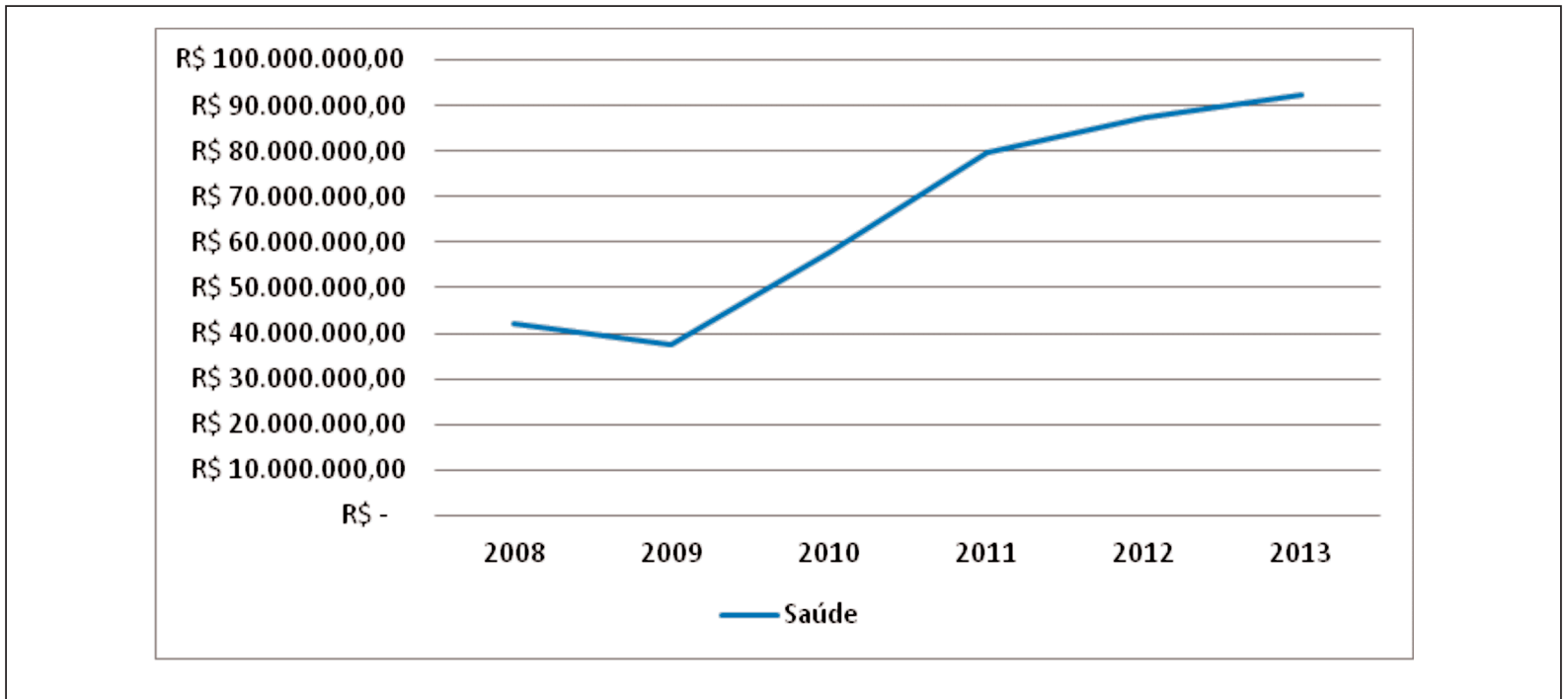

Fonte: Compilado a partir de Prefeitura (2014).

Não foi possível fazer uma análise dos componentes dos gastos com saúde para os anos 2011 e 2012 devido à falta de informações. No entanto, verifica-se a baixa preocupação com a prevenção. As subfunções atenção básica, vigilância sanitária, vigilância epidemiológica e alimentação e nutrição somam apenas 4\% das despesas com saúde. Enquanto isso, os gastos com a administração geral chegam a 70\%.

\subsection{Cultura, Saneamento e Lazer}

Os gastos com cultura mostraram um crescimento vertiginoso quando analisado apenas o período de 2009 a 2012, quando cresceu 290\%. No entanto, esse crescimento perde força em 2013 e cai 68\%. Por outro lado, os gastos com desporto e lazer caíram constantemente, saindo de R\$ 891.074,80 em 2008, para R\$ 118.829,10 em 2013.

A razão para uma volatilidade tão grande no orçamento da cultura pode estar ligada ao financiamento de shows milionários com grandes artistas nacionais. Em uma democracia de baixa intensidade e que não possui canais de diálogo e participação efetivos, repete-se esse padrão de gastos comum no Brasil. Por exemplo: entre 2 e 6 de julho deste 2014 realizou-se a 21 EXPO de Itaguaí no Parque de Exposições. A despesa com shows (sem contar a infraestrutura e outras despesas), para pagamento de artistas de projeção nacional atingiu 1,66 milhão de reais (Edição 351 do Jornal Oficial de Itaguaí, página 5, de 06/06/2014). Se houvesse uma discussão de prioridades, possivelmente a opção seria pela não realização desta forma, talvez com a opção de artistas da região que carecem de espaços para apresentação na grande mídia e, pelo visto, também nos eventos locais. 
Gráfico 6

Despesas Funcionais - Cultura, Saneamento e Desporto e Lazer

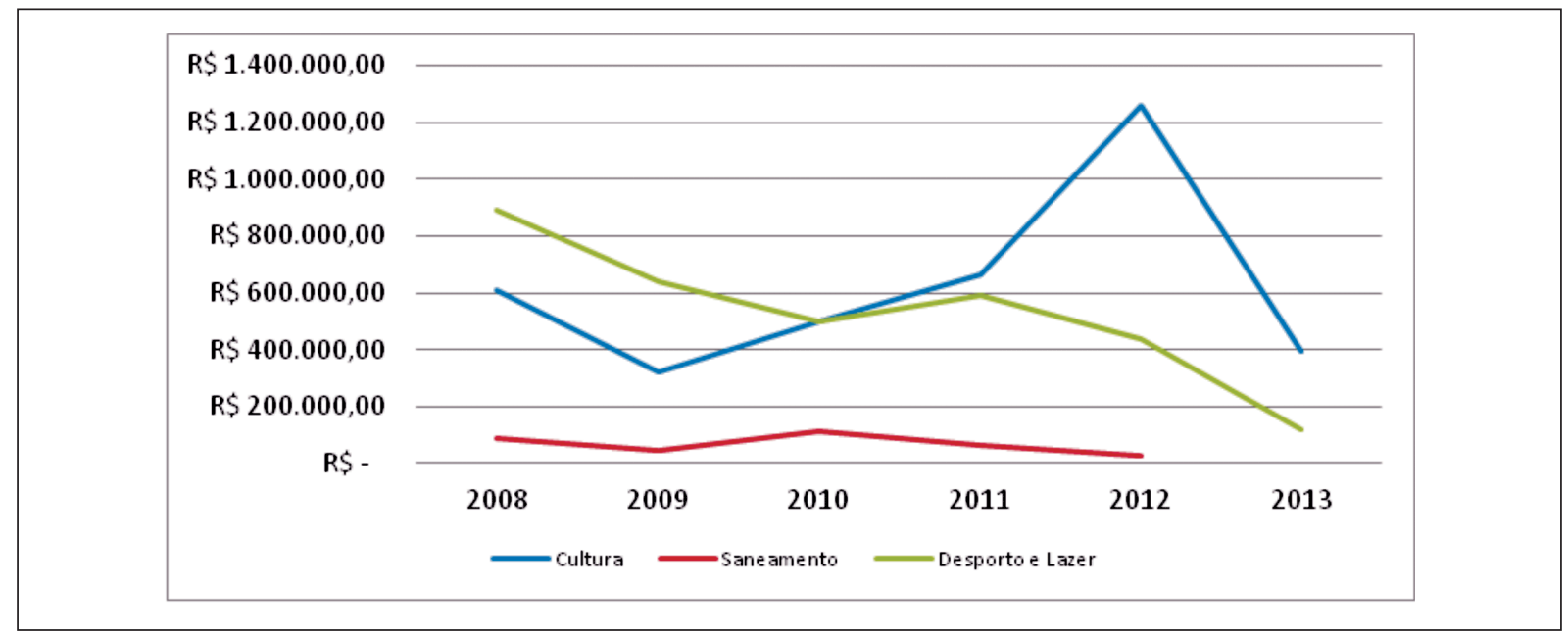

Fonte: Compilado a partir de Prefeitura (2014).

Não foi possível encontrar os números de 2013 para os gastos com saneamento, mas mesmo assim pode-se observar que eles nunca foram muito vigorosos, ficando em torno de R \$ 66 mil. Em uma cidade que apresenta perspectivas de crescimento populacional vigorosas em função dos GPIs, é extremamente grave que não haja investimentos em saneamento básico na mesa proporção.

\section{4 - Transportes}

Os gastos com transporte cresceram 53\% entre 2008 e 2013, com seu pico em 2012, quando acumulou um crescimento de $173 \%$ em relação a 2008 . Na realidade, sabe-se que o transporte público em Itaguaí é de baixíssima qualidade e que a população local reclama da demora, especialmente depois que as vans foram tiradas de circulação. Dessa forma, os dados de gastos com transporte não condizem com a realidade e indicam mau uso do dinheiro público.

Gráfico 7

Gastos com Transporte

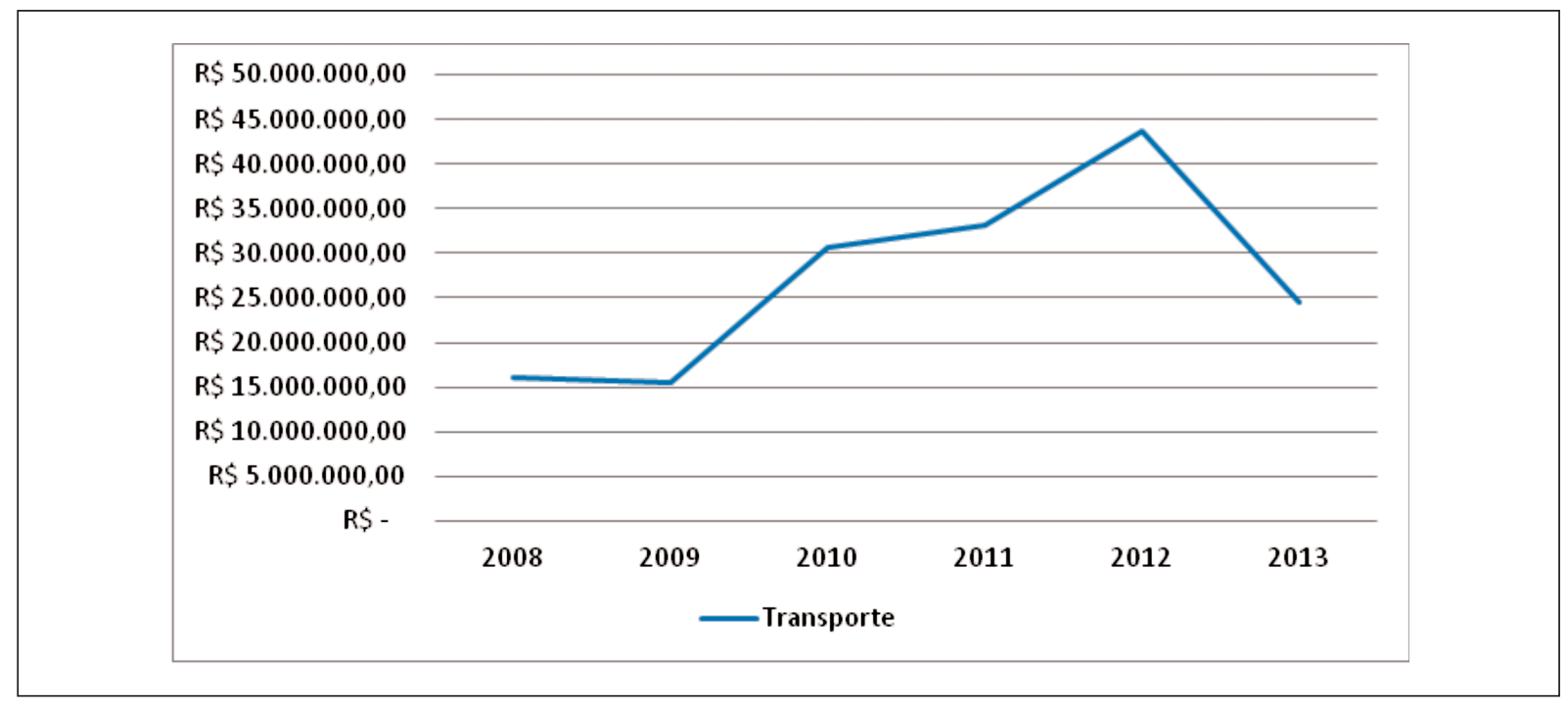

Fonte: Compilado a partir de Prefeitura (2014).

A prefeitura ainda declara em seu site na internet que, no período analisado, $65 \%$ dos 
recursos foram aplicados em serviços urbanos do transporte. Os outros 35\% foram para a administração.

\section{5 - Participação Social}

Observa-se no Mapa 1 que, dentre 20 conselhos municipais existentes em Itaguaí, apenas 8 (oito) realizam reuniões periodicamente, fazem ata e possuem arquivos com documentos das reuniões. Um conselho faz reunião periodicamente, mas não faz ata de reunião e possui alguns arquivos. De outro lado, a maioria dos conselhos (onze) não faz reuniões com periodicidade e tem representatividade ínfima em relação ao poder público.

FIGURA 3

Conselhos comunitários de Itaguaí e nível de atividade

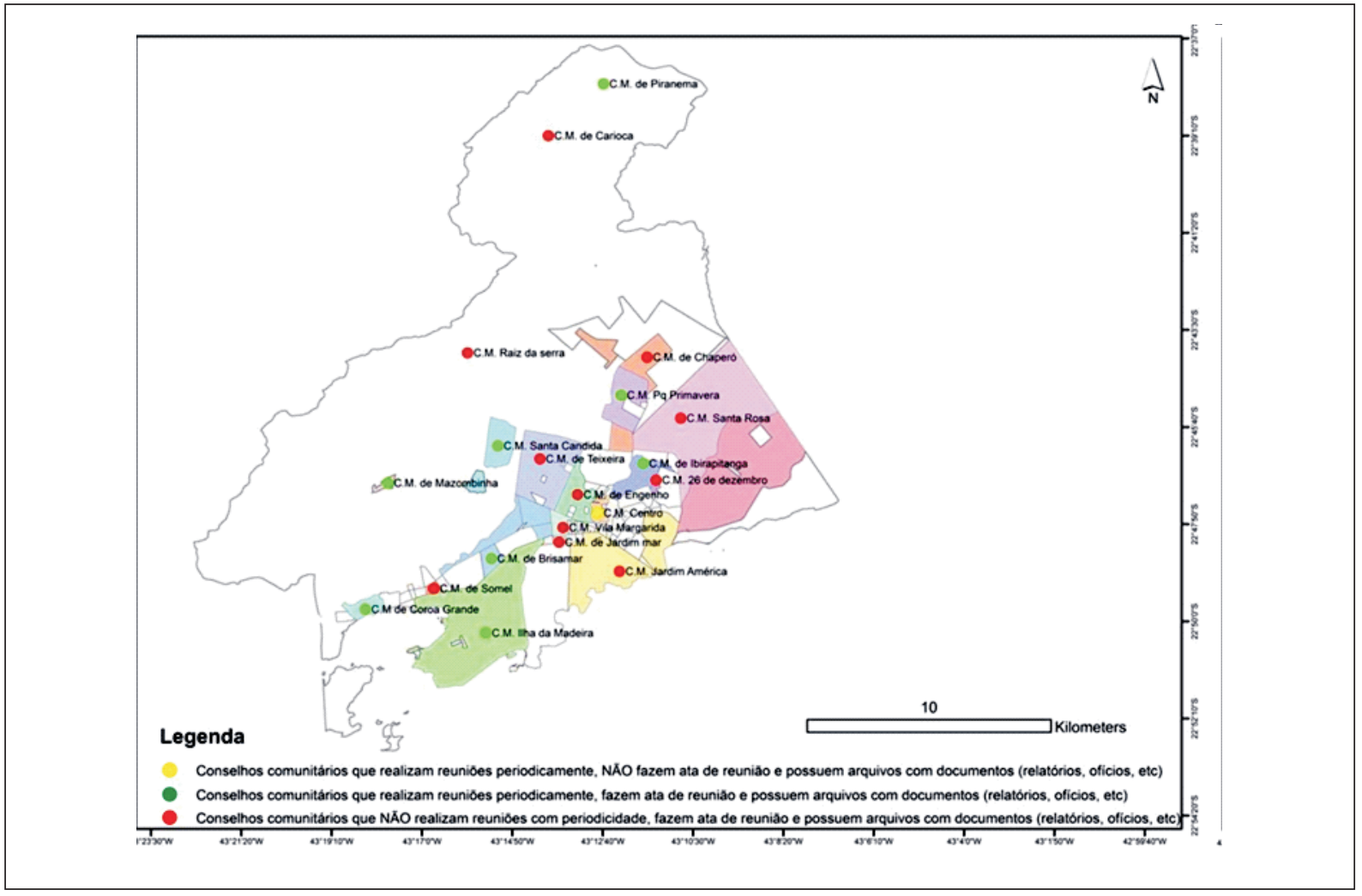

Fonte: Ferraz (2014).

Observa-se que a baixa participação social nas decisões tomadas pelo município agrava os impactos negativos provenientes dos GPIs. Ferraz (2014) aponta a falta de conhecimento da lei que estabelece o PDDSMI (Plano Diretor de Desenvolvimento Sustentável do Município de Itaguaí). A participação da sociedade fica comprometida na medida em que as informações não chegam à população, o que dificulta a prática dialógica dos atores sociais na formulação e implementação das políticas públicas que poderiam fazer frente aos impactos dos GPIs. Apesar de o Estatuto da Cidade e o PDDSMI instituírem o sistema de participação das comunidades organizadas de Itaguaí na gestão democrática da política urbana municipal, pode-se observar a falta de transparência e interação entre o poder público e a sociedade civil para pensar de forma democrática a política urbana municipal.

A gestão social busca substituir a gestão burocrática e monológica, por um gerenciamento participativo e dialógico, pelo qual o poder de decisão é deliberado pelos vários atores sociais envolvidos. No Município de Itaguaí, sociedade, poder público e mercado não dialogam acerca do desenvolvimento local da cidade, o que reforça a sensação de que os conselhos 
foram criados apenas como forma burocrática de cumprir o estabelecido em lei. Juntam-se questões institucionais, socioeconômicas e políticas que dificultam a atuação dos conselhos comunitários no acompanhamento e gerenciamento dos impactos gerados pelos GPIs tais como: dificuldade de saber o seu papel; falta de conhecimento do estabelecido no PDDSMI; cultura popular de não participação social nas decisões do poder público; centralização das decisões no poder público; agenda governamental estabelecida sobre influência dos grandes empreendimentos. Assim, os conselhos comunitários como ferramenta de gestão social se colocam como uma estrutura ameaçada, na medida em que não conseguem direcionar a formulação de políticas públicas no sentido de utilizar o aumento de receitas provenientes dos GPIs para melhorar a qualidade de vida da população local.

\section{Considerações finais}

Conforme discutido neste artigo, a importância da gestão social para a melhor condução dos impactos gerados pelos GPIs passa pela sensibilização, articulação e coordenação do desenvolvimento territorial sustentável, priorização dos projetos pretendidos no âmbito do território, articulação de arranjos institucionais responsáveis pela sua elaboração e implantação, monitoramento e avaliação do processo de desenvolvimento territorial.

No caso de Itaguaí, grande parte dos resultados encontrados através dos números do município revela uma cidade robusta economicamente, com crescimento das receitas nos últimos anos superior à média nacional e crescimentos expressivos nas taxas de investimento. No entanto, um olhar mais cuidadoso revela a dificuldade do município de levar em conta as questões do desenvolvimento territorial sustentável. O argumento deste artigo passa pela afirmação de que boa parte desse problema pode ser explicado pela pouca relevância dos atores sociais locais no processo decisório. Ou seja, conforme Vainer (2001) - que enfatiza as relações de poder entre o local e o global e questiona o que pode o poder local em seu texto -, o local pode prevalecer sobre o global, mas, para tanto, é necessária a construção de estratégias locais para enfrentar a lógica global.

Desta forma, como foi observado, o aumento das receitas em Itaguaí a partir do início das inversões dos GPIs não se refletiu na melhoria da qualidade de vida da população local nas diversas áreas analisadas. Além disso, verificou-se que a participação social no Município de Itaguaí é pouco ativa, traduzindo a baixa coesão social, territorial e de sustentabilidade. No que se refere à governabilidade, verificou-se que o plano diretor não foi elaborado participativamente, como consequência a Lei de Diretrizes Orçamentárias e a Lei Orçamentária Anual seguiram o mesmo modelo. A autonomia financeira melhorou com as inversões de impostos decorrentes da implantação dos megaempreendimentos, no entanto, não houve transparência na prestação de contas, já que os dados no site da Prefeitura apresentam-se de forma heterogênea de ano para ano dificultando uma avaliação longitudinal das informações. Da mesma forma, não houve promoção de consultas públicas para decisões de investimento, o que, nesta perspectiva, compromete o gerenciamento dos impactos gerados pelos GPIs.

Verificou-se, assim, que não houve a integração de setores locais e o planejamento da capacidade de atender às demandas da sociedade civil decorrentes do crescimento econômico. Com os novos investimentos foram criados mais postos de trabalho, sobretudo na construção civil. Poucos cursos de capacitação foram criados, destaca-se a implantação 
de uma unidade do SENAI em março de 2011. O PIB e investimento per capita cresceram bastante, mas é importante destacar que este não se traduz em inclusão econômica.

Observou-se ainda um crescimento no investimento em espaços de lazer e programas culturais, mas com uma representatividade ínfima destes gastos nos investimentos de infraestrutura urbana totais. No transporte público, o crescimento populacional sem planejamento já vem intensificando os problemas na mobilidade urbana. A saúde apresenta sérios problemas e a educação melhorou para o ensino básico, porém de forma localizada, mas não condiz com o montante de investimentos declarados pela Prefeitura.

Como resultado, observamos que as políticas em Itaguaí seguiram a modelagem topdown que tende a defender os interesses de grupos específicos, logo as benesses trazidas pelos megaempreendimentos, qual sejam o aumento dos investimentos, da renda per capita e do emprego, não se traduzem em melhoria da qualidade de vida para a população e ainda geram diversos impactos negativos. Nota-se, portanto, um distanciamento da modelagem do tipo bottom-up. Por isso, a noção de gestão social e cidadania deliberativa está imbricada ao processo de desenvolvimento territorial sustentável, com todas as suas categorias de análise. O caso de Itaguaí é singular e se destaca diante de outros municípios brasileiros pelo rápido crescimento da economia na última década. Estima-se que a população deverá crescer exponencialmente nos próximos anos, ampliando os problemas de locais. Ao evidenciar a pouca expressão da gestão social na condução das políticas públicas do município, sobressai a situação paradoxal de melhoria de indicadores socioeconômicos municipais e pouco avanço nas áreas sociais e infraestrutura.

O equilíbrio entre as demandas da sociedade civil, do mercado e dos poderes públicos visa o bem comum, não sendo possível a sustentabilidade que não esteja calcada no tripé citado por Sachs (2008): economicamente viável, ambientalmente correto e socialmente justo. Desta forma, caso não haja mudanças no rumo que vem sendo tomado no município, pode-se a priori imaginar que o cenário predominante será o de agravamento dos problemas sociais, ambientais e o enfraquecimento de instituições locais. Aspectos estes característicos de um processo de desterritorialização.

\section{Referências Bibliográficas}

ARAGÃO, L. M. de C. Razão Comunicativa e teoria social crítica em Jürgen Habermas. Rio de janeiro: Tempo Brasileiro, 1992.

ATLAS BRASIL - Programa das Nações Unidas para o Desenvolvimento; Instituto de Pesquisa Econômica Aplicada; Fundação João Pinheiro. Atlas do Desenvolvimento Humano no Brasil 2013. Disponível em: http://www.atlasbrasil.org.br/2013. Acesso em: 06 ago. 2013.

BNDES. Banco Nacional de Desenvolvimento. Disponível em: http://www.plataformabndes. org.br/site/. Acesso em: 27 mar. 2014

BOURDIEU, Pierre - Les structures socials de l'économie. Paris: Seuil, 2000.

BOTREL, M. de O.; ARAÚJO, P. G. de; PEREIRA, J. R. Entre a Gestão Pública e a Gestão Social de Bens Culturais no Brasil. In: ENCONTRO NACIONAL DE PESQUISADORES EM GESTÃO SOCIAL, 4, 2010, Lavras. Anais..., Lavras: INCUBACOOP, 2010. 1 CD ROM 
BRANDÃO, Carlos. Desenvolvimento nacional, políticas regionais e o poder de decisão segundo Celso Furtado. Cadernos do Desenvolvimento, vol. 7, pp. 101-115, 2010.

COBRAPE. Companhia Brasileira de Projetos e Empreendimentos. Disponível em: http:// www.cobrape.com.br/. Acesso em: 09 jul. 2014.

ESTATUTO DA CIDADE. Lei número 10.257 de 10 de julho de 2001. Disponível em: http:// www.planalto.gov.br/ccivil_03/leis/. Acesso em: 03 ago. 2013.

FERRAZ, Lucimar de Andrade Macedo. Análise da atuação dos Conselhos Comunitários enquanto instrumento de acompanhamento e participação na implementação do Plano Diretor de Desenvolvimento Sustentável do Município de Itaguaí - RJ. Dissertação PPGDT/ UFRRJ, Rio de Janeiro, 2014.

FIRJAN - Federação das Indústrias do Estado do Rio de Janeiro. Índice FIRJAN de Gestão Fiscal. Disponível em: http://www.firjan.org.br/data/pages/2C908CE9234D9BDA01234E532 B007D5D.htm. Acesso em: 01 ago. 2012.

FISCHER, T. M D. Poderes locais, desenvolvimento e gestão - uma introdução a uma agenda. In: FISCHER, T. M D. (Org.). Gestão do desenvolvimento e poderes locais: marcos teóricos e avaliação. Salvador: Casa da Qualidade, 2002. pp. 12-32.

.; MELO, V. P. Gestão Social do Desenvolvimento e Interorganizações. In: COLÓQUIO INTERNACIONAL SOBRE PODER LOCAL, 9, 2003, Salvador. Anais..., Salvador: CIAGS/ UFBA, 2003. 1 CD ROM

.; __ . Programa de desenvolvimento e gestão social: uma construção coletiva. In: FISCHER, T. M. D.; ROESCH, S.; MELO, V. P. Gestão do desenvolvimento territorial e residência social: casos para ensino. Salvador: EDUFBA, CIAGS/UFBA, pp. 13-41, 2006.

FLIGSTEIN, N. Social skill and the theory of fields. Sociological Theory vol. 19, n.

2, pp. 105-125, 2001. Disponível em: http://repositories.cdlib.org/cgi/viewcontent. cgi?article $=1000 \&$ context $=$ iir/ccop- Acesso em: 6 maio 05 .

FRANÇA FILHO, G. C. de. Definido Gestão Social. In: SILVA JR, J. T.; MÂISH, R. T.; CANÇADO, A. C. Gestão Social: Práticas em debate, teorias em construção. Fortaleza: Imprensa Universitária, 2008.

EPSJV/Fiocruz - ESCOLA POLITÉCNICA DE SAÚDE JOAQUIM VENÂNCIO E FUNDAÇÃO OSWALDO CRUZ. Território de Sacrifício ao Deus do Capital: o caso da Ilha da Madeira. In: A construção compartilhada de cenários exploratórios e prospectivos entre atores envolvidos em conflitos socioambientais - o caso do passivo ambiental da Companhia Mercantil e Industrial Ingá. Rio de Janeiro, 2010. Disponível em: < http://www.epsjv.fiocruz.br/index. php?Area $=$ Material\&Num=157> Acesso em: 15 mai. 2012.

FLIGSTEIN, Neil. The architecture of Markets - an economic sociology of XXI century capitalist societies. Princeton University Press, 2001.

FURTADO, Celso. Pequena introdução ao desenvolvimento. Rio de Janeiro: Nacional, 1980.

GAUDIN, J. P. Gouverner par contrat. Paris: Science Po, 2007.

HABERMAS, J. The theory of communicative action. Vol 1. Reason and the rationalizalion of society. Boston, Beacon Press, 1984. 
. The theory of communicative action. Vol 2. Lifeworld and sistem: A critique of functionalist reason. Boston, Beacon Press, 1987a.

. Mudança estrutural da esfera pública. Rio de Janeiro: Tempo Brasileiro, 1984.

HORKHEIMER, M. Teoria Tradicional e Teoria Crítica. In: HORKHEIMER, M.; ADORNO, T. W. Textos Escolhidos. São Paulo: Nova Cultural, 1989.

IBGE - Instituto Brasileiro de geografia e Estatística. IBGE Cidades. Disponível em: http:// cidades.ibge.gov.br/xtras/home.php. Acesso em: 27 nov. 2012.

INEA - INSTITUTO ESTADUAL DO AMBIENTE. Monitoramento de Qualidade da Água. Disponível em: < http://www.inea.rj.gov.br/fma/baia-sepetiba.asp> Acesso em: 10 mai. 2012. IPEA - Instituto de Pesquisa Econômica Aplicada. IPEADATA. Disponível em: http://www. ipeadata.gov.br/. Acesso em: 13 jun. 2012

ITAGUAÍ - Portal da Prefeitura www.itaguai.rj.gov.br Edição 351 do Jornal Oficial de Itaguaí, página 5, Disponível em: http://itaguai.rj.gov.br/pdfjornal/edicao351.pdf.

LASCOUMES, P.; LE GALÈS, P. (org.). Gouverner par les instruments. Paris: Science Po, 2004.

PARÉS, M; CASTELLÀ, C. Criteris, metodologies i reflexions entorn l'avaluació de la participació ciutadana. Barcelona: EPSU/IGOP/UAB, 2008. mimeo.

PERICO, R. E. Identidade e território no Brasil. Brasília: Instituto Interamericano de Cooperação para a Agricultura, 2009.

PINHO, J. A. G. de. Gestão social: conceituando e discutindo os limites e possibilidades reais na sociedade brasileira. In: RIGO, Ariádne Scalfoni; SILVA JÚNIOR, J. T; SCHOMMER, P. C; CANÇADO, A. C. Gestão Social e Políticas Públicas de Desenvolvimento: Ações, Articulações e Agenda. Recife: UNIVASF, 2010.

PINTO, J. M. de R. A teoria da ação comunicativa de Jürgen Habermas: conceitos básicos e possibilidades de aplicação à administração escolar. Paidéia (Ribeirão Preto), n. 8-9, Ribeirão Preto, ago. 1995.

PMI - Prefeitura Municipal de Itaguaí. Contas Públicas. Disponível em: http://www.prefeituraitaguai.com.br/novo_site/index.php >. Acesso em: 13 jun. 2012.

RIMA-COMPERJ, Relatório de Impacto Ambiental do Comperj, 2007. Disponível em: http://ecolimpico.wordpress.com/2012/07/20/arco-metropolitano-rodoviario-projeto-deinterligacao-se-transforma-em-vilao-das-familias-locais/ Acesso em: 20 ago. 2014.

SACHS, I. Desenvolvimento includente, sustentável sustentado. Rio de Janeiro: Garamond, 2008.

SANTANA. J. S, GUEDES, A. M. G, VILLELA. L. E. Desenvolvimento territorial sustentável e os desafios postos por megaempreendimentos: o caso do município de Itaguaí - RJ. Cad. EBAPE, vol. 9, n. 3, artigo 8, Rio de janeiro, set. 2011.

SEMAAP - SECRETARIA DE MEIO AMBIENTE, AGRICULTURA E PESCA - Prefeitura de Itaguaí - Centro Didático produtivo. Projeto e Ações - Compromisso, Trabalho e Seriedade, 2011.

SOUZA, C. O. de. Esforço fiscal e alocação de recursos nos municípios da Zona da Mata de 
Minas Gerais. 105f. Dissertação (Mestrado em Administração) - Universidade Federal de Viçosa, Viçosa, MG, 2007.

TENÓRIO, F. G. Tem razão a administração? 3. ed. Ijuí: Editora da Unijuí, 2008a. juí, 2008b.

. Um espectro ronda o terceiro setor, o espectro do mercado. 3. ed. Ijuí: Editora da Uni.; SARAIVA, H. J. Escorços sobre gestão pública e gestão social. In: MARTINS, P. E. M.; PIERANTI, O. P. Estado e gestão pública: visões do Brasil contemporâneo. 2. ed. Rio de Janeiro: FGV, 2006. 340p.

TCE - TRIBUNAL DE CONTAS DO ESTADO DO RIO DE JANEIRO. Estudos socioeconômicos. Disponível em: http://www.tce.rj.gov.br. Acesso em: 30 jan. 2013.

TENÓRIO, F. G. Cidadania e desenvolvimento local: critérios de análise. Rio de Janeiro: FGV Editora, 2012.

VAINER, Carlos Bernardo. A Escala do Poder e o Poder das Escalas: O que pode o poder local? Revista Brasileira de Estudos Urbanos e Regionais. Rio de Janeiro1: IPPUR/UFRJ, 2001.

VILLELA, L. E. Escopo Metodológico. In: TENÓRIO, F. G. (org.). Cidadania e desenvolvimento local: critérios de analise. Rio de Janeiro: FGV Editora, 2012.

VILLELA, L. E; GUEDES, C. A. M; SANTANA, J, S e BRITTO, E, B, R. Crescimento econômico versus gestão social e Desenvolvimento territorial sustentável. Análise dos Impactos de Megaempreendimentos nos Municípios de Macaé-RJ e de Itaguaí-RJ. Desenvolvimento em Questão. Ano 10, n. 21, Ijuí: Unijuí, set./dez. 2012. 